\title{
Male and female lecturers' politeness strategies in EFL classroom
}

\author{
Novianti Arif ${ }^{1}$, Iskandar ${ }^{2}$, A. Muliati ${ }^{3}$, Andi Anto Patak ${ }^{* 4}$ \\ Universitas Negeri Makassar, Faculty of Languages and Arts, English Department, \\ Makassar, 90221, Indonesia \\ e-mail:1'nopinopi94@gmail.com; ${ }^{2}$ iskandar@unm.ac.id; ${ }^{3}$ muliati.m@unm.ac.id; \\ *4andiantopatak@unm.ac.id
}

\begin{abstract}
This research identified types of politeness strategies used by a male and female lecturer in the EFL classroom based on the theory of Brown and Levinson. This research also investigated students' perception toward the use of lecturers' politeness strategies in the EFL classroom. This research applied the descriptive qualitative research design to describe the phenomena of politeness strategies. The subjects of this research were two English lecturers and fifteen university students. All of them chosen by using purposive sampling. The instrument of this research was observation and interview. The observation was conducted three meetings for every lecturer by using an audio recorder and field notes. The audio recorder was used to record lecturers' utterances in the teaching and learning process. The field notes were used to obtain more accurate data. The interview was conducted to get the data from the students. The interview is done to find out about the students' perception toward the use of politeness strategies in the classroom. The result of this research showed that male and female lecturers used four types of politeness strategies namely bald on-record, positive politeness, negative politeness, and off-record. Furthermore, the students perceived that male and female lecturer was polite. The students perceived that the male lecturer was more formal while the female lecturer was friendly.
\end{abstract}

\section{Keywords: \\ Politeness strategies; gender politeness; EFL classroom}

\section{INTRODUCTION}

Learning English as a foreign language means to know not only to speak and write but also using language appropriately (Samad, Fitriani, Patak, \& Weda, 2018). The ability to use language appropriately is called pragmatic knowledge. Pragmatic knowledge investigates the ability of language users to match utterances with a context in which appropriate (Bardovi-Harlig \& Mahan-Taylor, 2003). One of the pragmatic knowledge which influences the interaction between the lecturer and the students is politeness. There are several studies have been conducted about politeness in Asia. The studies describe politeness practice in specific society for example in China (Kádár \& Pan, 2011), Japan (Haugh \& Obana, 2011), Korea (Kim, 2011), Vietnam (Chew, 2011), and Singapore (Lee, 2011). In Indonesia, there is also research has been conducted about politeness. Mahmud (2013) has examined the roles of social status, age, gender, familiarity and situation in politeness practice. 
Politeness study is conducted in various context one of which is in the educational context. For example, Agustina and Cahyono (2016) have studied about Indonesian learners and lecturers' politeness and stated that EFL lecturers should be aware of the use of the polite expression to deliver instruction, request, and orders. Jiang (2010) stated that politeness enhances teaching and benefits to the students, contributes to the effective interaction and friendly, lively atmosphere in the EFL classroom. There are many factors which influence people to be polite such as social status, age, gender, familiarity, and situation. Millar (1983) has studied gender behavior regarding the social and symbolic dynamic of Bugis society and stated that men should behave aggressively and formally whereas women need to behave cautiously and informally. According to Brown in Mills (2003) that women, in general, are more polite than men. It is by Speer (2002) that women have a higher tendency than a man to apply politeness strategies in their speech such as the use more compliments, more apologies, and more thank.

Related to the title for this study, it is possible that a female lecturer is more polite than male lecturer. It is also possible between male and female lecturer to use a different kind of politeness strategies. Monsefi and Hadidi (2015) have studied about male and female EFL teachers' politeness strategies and the effect on the learning process and found that female teachers are more sensitive about using politeness strategies, but male teachers are more direct in expressing ideas, male teachers usually express their disagreement in a direct way. This study examines about the types of politeness strategies used by male and female lecturer in EFL classroom and the students' perceptions toward the use of lecturers' politeness strategies in EFL classroom.

\section{REVIEW OF RELATED LITERATURE}

\subsection{Politeness Strategies}

Politeness can be defined as showing awareness and consideration of another person's face (Yule, 2016). Face in pragmatic knowledge is public self-image. It is the emotional and social sense of self that everyone has and expects everyone else to recognize. According to Brown and Levinson (1987), that face is defined as the public self-image that every member wants to claim for himself and divided into two related aspects which are the negative face and positive face. The face could mean honor, self-esteem and public self-esteem. Politeness theory is divided into four types of strategies: bald on-record strategies, positive politeness, negative politeness, and off-record strategies.

Holmes (2013) stated that there is some social dimensions which have proved useful in analyzing linguistic politeness. These are the solidarity-social distance dimension, the power dimension, and the formality dimension. The relative social distance between the speaker and the addresses is the one factor of the most fundamental factors determining the appropriate level of politeness behavior in most. The fact that people work together will contribute to their feeling more friendly towards one another. The frequency of interaction is another essential factor to be considered in determining the degree of solidarity. 
The power is another important consideration in determining the appropriate degree of linguistic politeness. Power refers to the ability of the participant to influence one another circumstances. The distribution of power in a particular context may derive from a variety of source such as money, knowledge, social prestige, role and so on. The high power tends to attract deferential behavior, including linguistic deference or negative politeness. Then, the formality dimension can influence the expression of politeness. In general, negative politeness strategies will often occur in formal setting and interaction, while positive politeness tends to characterize a more intimate and less formal situation.

\subsection{Politeness Strategies by Gender}

Women and Men have different aims in conversation, which lead to breakdowns in communication or misunderstanding since women are concerned mainly to establish rapport between members of a group and to ensure that conversation goes smoothly (rapport talk). Men are concerned to establish their place in the pecking order and use the production of information as a way of establishing a position in the hierarchy (report talk) (Mills, 2003).

According to Holmes (2013), women are more polite than men. It depends on the meaning of politeness, and it depends which women and which men are comparing, and it also depends on the context. Also, men and women use language differently, and this is where the difference in politeness can be observed. Most women enjoy the talk and regard talking as an essential means of keeping in touch, especially with friends and intimates. They use language to establish, nurture and develop a personal relationship. Men tend to use language as a tool for obtaining and conveying information.

\section{Method}

The descriptive qualitative design was applied in this research. There were two lecturers, and 15 students of STAIN Watampone participated in this research. In collecting the data, the researcher observed and recorded the teaching and learning process. Afterward, the students were interviewed about the use of politeness strategies in the EFL classroom. In analyzing the data, the interactive model of Miles and Huberman (1994) was used. The data from the audio recording were transcribed. The result of observation and interview were analyzed. Afterward, the process of coding was applied and categorized based on the research questions addressed.

\section{Results}

\subsection{Types of Politeness Strategies Using by Male and Female Lecturers}

From the data analysis, the researcher found that four types of politeness strategies used by the male and female lecturer in the EFL classroom. They were a bald on-record strategy, positive politeness strategy, negative politeness strategy, and off-record strategy. The details finding are presented below: 


\subsubsection{Bald on-record strategy}

\subsubsection{Extract 1: giving comment}

In this situation, the male lecturer examined the students' writing. Then, $\mathrm{He}$ found the error in the student's writing.

In the teaching of Islam is...I think that it is a big problem here because when you saying the teaching of Islam, no subject and you used to be next. It is totally wrong. In the teaching, in-nya itu adalah preposisi. The teaching itu object of a preposition and of Islam juga object of a preposition. Jadi tidak ada subject dan kemudian ada to be is, jadi itu unstructured. Okay...baju bodo ini merupakan baju bodo tertua di dunia yang sudah dikenal oleh masyarakat Sulawesi Selatan sejak pertengahan abad ke-9. Iya?(L)

[In the teaching of Islam is... I think that it is a big problem. When you said the teaching of Islam, there is no subject and after that you used 'to be.' It is totally wrong. In the sentence 'in the teaching,' it is a preposition. The teaching is the object of a preposition and Islam is also the object of a preposition. Therefore, there is no subject in the sentence and then you put to be 'is'. So, it is unstructured. Okay...baju bodo is the oldest clothes known by the people in South Sulawesi since the mid-9 $9^{\text {th }}$ century. Right?]

In the extract above, the bald on-record strategy was used by the male lecturer in the classroom. The lecturer did the FTAs without minimizing the imposition of the student's positive face. The utterance it is totally wrong showed that no redress is required. He expressed his disagreement directly.

\subsubsection{Extract 2: giving the command}

This situation is the beginning of the learning activity. After greeting, the female lecturer instructed the students.

Assalamualaikum Warahmatullahi Wabarakatu...Take a piece of paper! Yap sudah? number one

[Assalamualaikum Warahmatullahi Wabarakatu...Take a piece of paper! Yap. Done? Number one.] (L)

Belum bu [Hold on, Mom](Ss)

Based on the extract above, bald on record was applied by the female lecturer in the classroom. After greeting, she instructed the students to take a piece of paper. The utterance used by the lecturer was very clear and unambiguous. It was 'Take a piece of paper!'

\subsubsection{Positive politeness strategy}

\subsubsection{Extract 3: joke}

This situation happened when the male lecturer asked the student about how to say in English daun suji.

Daun suji, apa ini daun suji?

[Daun suji. What is daun suji?](L)

Daun pandan (Ss)

Ya pandan bahasa indonesianya. Suji? Bahasa Indonesia juga?

[Yes. Pandan in Indonesian. Suji? Is it Indonesian?](L)

Bahasa Indonesia pak.

[Indonesian, Sir](S) 
Suji ini kayak lagu Rhoma irama ini..suji (singing)

[Suji is like Rhoma Irama's song...Suji (singing)] (L)

<@Judipak@>

$<@ J u d i$ Sir@ $>$ ](Ss)

In this extract, the male lecturer expressed positive politeness. The utterance Suji is like Rhoma Irama's song...Suji was joke. He said the utterance Suji with a tune of a song. After hearing the utterance, the students knew what the lecturer means. Then, they laughed and said Judi Sir (Judi is a title of the song).

\subsubsection{Extract 4: joke}

This situation happened when the female lecturer and the students corrected the sentence. She asked the students the meaning of a word in English.

Iya, knalpot. Apa yang seharusnya disitu?

[Yes, knalpot. Is it the correct one?] (L)

Muffler (S)

Muffler. Itu Bahasa Indonesia ya, jadi?

[Muffler. Is it Indonesian right? So?] (L)

Wrong word bu (S)

Yes. Bahasa bugisnya kendaleppo

[Yes. In Bugis term kendaleppo] (L)

(laugh) (Ss)

The female lecturer applied positive politeness in the extract above. The extract above shows how she responded when the student's answer was correct. The female lecturer used the term in Bugis 'Kendaleppo' [muffler] to tease the students. After the lecturer said that term, the students immediately laugh. Because the lecturer and the students shared the same background knowledge, they can understand the lecturer's point.

\subsubsection{Extract 5: praising the students}

The male lecturer evaluated student' translation work. He asked the student to correct her writing and send to him.

Diperbaiki ya baru dikirim. Khusus untuk closing statement dengan reference. Yang tadi ya singular jadi plural...(7). Ini mantap sekali ini. Saya suka ini. Diperbaiki riska ya,. Saya kasih seratus tapi diperbaiki. Okay sudah. Satu lagi. Waduh sepuluh tiga puluh ya? Aduh. Masih bisa bertahan untuk ini?

[You should correct it, then send it. Especially for the closing statement and the reference. Change the word from singular to plural...(7) This is very good. I like this. . I give you 100 but you need to correct it. Okay, it is done. One more. It is 10.30 a.m, right? Can we continue for a few minutes? (L)

Bisa pak

[Yes, Sir] (Ss)

Based on the extract above, positive politeness was found. The lecturer used the utterance 'Ini mantap sekali' [this is very good] to praise his student. It kinds of utterances which affect the student's positive face. This strategy was 
named to give gifts to $\mathrm{H}$ which the speaker noticed the hearers wants giving praise.

\subsubsection{Extract 6: praising the students}

In this situation, the female lecturer asked the student to read the description of what she wrote about her best friend. Her best friend is her sister.

Yes...Her character is very kind but she also angry to me when I forget clean my room. (S)

Yes, good. Next, Wahyudi (L)

Name rizki aminullah. Age, twenty. Hobby ee (S)

Positive politeness was found in this extract. The student gave her opinion about her sister. The female lecturer used the utterance 'Yes, good' to respond to the student's opinion. This is kinds of utterances affected the student's positive face. This strategy was named give gifts to $\mathrm{H}$ which the speaker noticed the hearers wants y giving praise.

\subsubsection{Negative politeness strategy}

\subsubsection{Extract 7: question}

This situation happened when the male lecturer read the student's writing assignment.

Okay, it is good enough...long time Buginese always make, apa maksudnya long time buginese? Orang bugis sudah lama sekali membuat itu ya maksudnya? Kalo long time buginese apakah konteksnya betul itu? Apakah itu maksudnya? Long time buginese always, sudah lama orang bugis selalu membuat sawa'. Benar nda ini?

[Okay, it is good enough... 'long time Buginese always make,' what does it mean 'long time bugenese'? Bugis people have made it for long time ago, isn't it? Is the context of 'long time bugenese' appropriate? What does it mean? 'long time bugenes always', it had been long time bugis people make sawa'. Isn't right?] (L)

Benar kalo dalam speaking

[It is appropriate in speaking] (S)

Iya, benar kalo dalam spoken language, tapi kalo penulisan jangan long time.

[Yes it is appropriate in spoken language. Don't use it in written language] (L)

Based on the extract above, the male lecturer applied negative politeness when commenting on a student's writing assignment. The lecturer preferred to ask a question to the students instead of assuming by himself about the statement in the student's writing. The use of question tag 'isn't right?' indicate that the lecturer's lack of commitment to the truth of a statement.

\subsubsection{Extract 8: question}

This situation happened at the beginning of the teaching activity. The female lecturer asked the students about the last meeting.

The last meeting for the material. Untuk materinya materi terakhir ini kan? Tinggal peer teaching. Tapi, kelompok lain tidak melakukan peer teaching Karena katanya sudah masuk di microteaching

[The last meeting for the material. Is this the last for the material, right? It is peer teaching. However, the other class do not do peer teaching because it is done in microteaching] (L) 
Yes mam, sudah di microteaching

[Yeas, mam. It is done in microteaching] (Ss)

Jadi, penggantinya final test.

[So, it is replaced with final test] ( $L$ )

Based on the extract above, the female lecturer used negative politeness strategy. The utterance this is the last material, 'isn' $t$ it?' was conveyed by the lecturer because he did not assume by herself about the last material.

\subsubsection{Off-record strategy}

\subsubsection{Extract 9: give a hint}

In this situation, the male lecturer and the student talked about the traditional clothes namely baju bodo.

baju bodo merupakan baju bodo tertua di dunia yang sudah dikenal oleh masyarakat Sulawesi Selatan sejak pertengahan abad ke-9. Iya?

[= This baju bodo is the oldest baju bodo in the world which has been known by people in South Sulawesi since the mid-19th century. Isn't it? (L)

iya

[Yes, it is] (S)

Kata siapa ini?

[Who says this?] (L)

artikelnya susi pak

[It is Susi's article Sir] (S)

Susi? Susi ahli sejarah? Jadi kalo pespektif sejarah harus jelas ya.

[Susi? Is Susi a historian? So, the historical perspective should be clear ok?] (L)

Iya pak

[Yes $\operatorname{Sir}](\mathrm{S})_{\mathrm{s}}$

The extract above showed that the male lecturer applied off record. The utterance 'Kata siapa ini?' [who says this?] was actually used by lecturer to say something implicitly. He tried to invite student to interpret that the student need to put the reference in her article. But, the student seems to find difficult to understand his hint. Then, she said 'Susi ahli sejarah? Jadi kalo pespektif sejarah harus jelas ya' [Susi? Is Susi a historian? So, the historical perspective should be clear ok?]

\subsubsection{Extract 10: understating the students}

In this situation, the female lecturer asked a student about the meaning of the phrase. The student found the difficulty to find the meaning.

$Y a$, this card is [a] writing sample about describing friend, you need to put in order. Khaerati, what [do] you have to do? (L)

Put in order (S).

Put in order. Rima, what is put in order? (L)

heemm...(S)

Iye? apa itu put in order? put in order ...Ya, susunki. Waa bahaya ini, sudah mau seminar. 
[Ya? What is put in order? Put in order...Ya, you need to arrange. Waa, it is terrible. You will have a seminar soon] (L)

In this extract, off-record was applied by the lecturer. The utterance ' $W a a$ bahaya ini, sudah mau seminar' [Waa, it is terrible. You will have a seminar soon] indicated that the lecturer considered the student should know about the meaning of the phrase which was asked by her. Then, the lecturer conveyed her indirect about what he intends to convey.

\subsection{Students' Perception toward the Use of lecturers' Politeness Strategies}

The researcher displayed the students' perception toward the use of lecturer's politeness into the following Table 1.

Table 1. The students' perception toward the use of lecturers' politeness by gender

\begin{tabular}{|c|c|c|}
\hline $\begin{array}{l}\text { Male' } \\
\text { Perception }\end{array}$ & Male lecturer & Female lecturer \\
\hline $\begin{array}{l}\text { The lecturer } \\
\text { is polite }\end{array}$ & $\begin{array}{l}\text { The lecturer asks the } \\
\text { students first before } \\
\text { asking a question } \\
\text { - The lecturer corrects the } \\
\text { student's answer and } \\
\text { praises them }\end{array}$ & $\begin{array}{l}\text { - The lecturer corrects the } \\
\text { students' answer and explains it } \\
\text { - The lecturer pay attention to all } \\
\text { students } \\
\text { - The lecturer makes a joke with } \\
\text { the students } \\
\text { - The lecturer asks the students to } \\
\text { discuss the material } \\
\text { - The lecturer can be friendly with } \\
\text { the students in the classroom }\end{array}$ \\
\hline $\begin{array}{l}\text { The lecturer } \\
\text { is less polite }\end{array}$ & $\begin{array}{l}\text { - The lecturer does not pay } \\
\text { attention to all the } \\
\text { students when teaching } \\
\text { the process } \\
\text { - The lecturer does not } \\
\text { focus on the material }\end{array}$ & $\begin{array}{l}\text { - The lecturer directly point the } \\
\text { students when asking a question }\end{array}$ \\
\hline
\end{tabular}

\begin{tabular}{lll}
\hline \hline Females & Male lecturer & Female lecturer \\
Perception & & \\
\hline
\end{tabular}

\begin{tabular}{|c|c|c|}
\hline $\begin{array}{l}\text { The lecturer } \\
\text { is polite }\end{array}$ & $\begin{array}{l}\text { - The lecturer asks the } \\
\text { students first before } \\
\text { asking a question } \\
\text { - The lecturer gives the } \\
\text { opportunity for every } \\
\text { student asking a question } \\
\text { - The lecturer corrects the } \\
\text { students' answer and } \\
\text { praises them }\end{array}$ & $\begin{array}{l}\text { - The lecturer correct the } \\
\text { students' answer and explains it } \\
\text { - The lecturer pay attention to all } \\
\text { students } \\
\text { - The lecturer makes a joke with } \\
\text { the students } \\
\text { - The lecturer interact with the } \\
\text { students in the classroom }\end{array}$ \\
\hline
\end{tabular}


- The lecturer can be friendly with the students in the classroom

$\begin{array}{lll}\begin{array}{l}\text { The lecturer } \\ \text { is less polite }\end{array} & \begin{array}{l}\text { - The lecturer judge the } \\ \text { students' answer }\end{array} & \begin{array}{l}\text { - The lecturer directly point the } \\ \text { students when asking a question }\end{array} \\ & \begin{array}{l}\text { - The students cannot } \\ \text { understand the lecturer's } \\ \text { utterances }\end{array} & \begin{array}{l}\text { - The lecturer judge the students' } \\ \text { answer }\end{array} \\ \text { - The lecturer does not } & \\ \text { interact with the students } & \\ \text { in the classroom }\end{array}$

\section{DISCUSSION}

Based on the findings stated previously, politeness strategies used by male and female lecturer in the EFL classroom covers all types of politeness strategies (Brown \& Levinson, 1987). The finding reveals that the bald on-record strategy was used by the male lecturer when giving comments to the students. Meanwhile, the female lecturer used this strategy when giving the command to the students. The characteristic of this strategy is direct, clean, unambiguous and concise. Leech (2014) stated that the utterance expressed indirectly more polite than the utterance expressed directly. The bald on-record strategy used by male and female lecturers in the classroom can be considered impolite. The different kinds of bald on-record usage in different circumstances were because the lecturers have different motives. The use of bald on-record strategy in the classroom is acceptable because the lecturers have power and between the lecturer and the students are mutually known. However, the researcher thinks that the female lecturer is more polite than the male lecturer. The researcher thinks that the use of this strategy when giving a command to the student is possible because the maximum efficiency is needed. However, it is different from the male lecturer. Although the male lecturer also has the power in the classroom he may be considered less polite because he uses a bald onrecord strategy to convey the student's defeat.

Positive politeness strategy encompasses the most often used by the male and female lecturer. Generally, the lecturers applied this strategy to show their appreciation, approval, and interest to the students. Agustina and Cahyono (2016) stated that the lecturers should use polite utterances in the classroom to make the students feel comfortable and appreciated. The findings also found that the male and female lecturer tended to apply negative politeness strategy by minimizing imposition of the students' negative face. Then, the off-record strategy was used by the lecturers when they conveyed their intention. It allows the students to realize their mistake without the lecturer directly state it.

The findings also discussed the students' perception toward the use of lecturers' politeness strategies. The students perceived that the male lecturer was more formal when communicating with them. Holmes (2013) stated that the formality could influence the expression of politeness and negative 
politeness strategies will occur more often in formal setting and interaction, while positive politeness tends to characterize more intimate and less formal situation. This supported by Millar (1983), men need to behave aggressively and formally whereas women need to behave cautiously and informally. The male lecturer tends to focus on conveying the information rather than a personal relationship. This supported by Mills (2003)that women and men have different aims in conversation. Women are primarily concerned to establish rapport between members of a group and to ensure that conversation goes smoothly (rapport talk), while men are concerned to establish their place in the pecking order and use the production of information as a way of establishing a position in the hierarchy (report talk).

Meanwhile, the female lecturer is more friendly, intimate and humorous. Most of the students think that the female lecturer can make them enjoy and feel comfortable in studying English. This is supported by Sülü (2015), politeness helped the students to have a positive feeling toward the lesson and motivated them to participate more in class. The students perceived that the male and female lecturer have different politeness in the classroom. The male lecturer is not really to the point when he asks a question. It is not relevant with Lakoff (2004), that male speech is characterised as direct, forceful and confident. The students stated that he frequently used praise to appreciate the students. Positive politeness strategy includes making the students comforted and being appreciated. The female lecturer is very clear and not perplexing when asking a question to the students. The students said that the female lecturer points the students directly. It is opposite with Lakoff (2004) which stated that woman's language style is further characterised as indirect.

\section{CONCLUSION}

The types of politeness strategies used by male and female lecturer included four types of politeness strategies by Brown and Levinson (1987) theory. Those were bald on-record, positive politeness, negative politeness, and offrecord. Then, male lecturer tended to use positive politeness and negative politeness while female lecturer preferred to use bald on-record strategy. Most of the students perceived that male and female lecturer is polite. They perceived that the male lecturer is more formal and serious when interacting with them. However, the female lecturer is friendly, intimate and humorous. They explained that the female lecturer makes them enjoy and feel comfortable in studying English.

\section{REFERENCES}

Agustina, S., \& Cahyono, Y. B. (2016). Politeness and Power Relation in EFL Classroom Interactions: A Study on Indonesian Learners and Lecturers. International Journal of Language and Linguistics, 3, 92-100.

Bardovi-Harlig, K., \& Mahan-Taylor, R. (2003). Teaching pragmatics. Washington DC: US Department of State Office of English Language Programs.

Brown, P., \& Levinson, S. C. (1987). Politeness: Some universals in language usage (Vol. 4). Cambridge university press.

Chew, G. C. L. (2011). Politeness in Vietnam. Politeness in East Asia, 208-225.

Haugh, M., \& Obana, Y. (2011). Politeness in Japan. Politeness in East Asia, 147-175. 
Holmes, J. (2013). Women, men, and politeness. Routledge.

Jiang, X. (2010). A case study of teacher's politeness in EFL class. Journal of Language Teaching and Research, 1(5), 651-655.

Kádár, D. Z., \& Pan, Y. (2011). Politeness in China. Politeness in East Asia, 125-146.

Kim, A. H.-O. (2011). Politeness in Korea. Politeness in East Asia, 176-207.

Lakoff, R. T. (2004). Language and woman's place: Text and commentaries. (M. Bucholtz, Ed.) (Vol. 3). Oxford University Press, USA.

Lee, C. L. (2011). 10 Politeness in Singapore. Politeness in East Asia, 226.

Leech, G. N. (2014). The pragmatics of politeness. Oxford Studies in Sociolinguistic.

Mahmud, M. (2013). The roles of social status, age, gender, familiarity, and the situation in being polite for Bugis society. Asian Social Science, 9(5), 58.

Miles, M. B., \& Huberman, A. M. (1994). Qualitative data analysis: An expanded sourcebook. Sage.

Millar, S. B. (1983). On interpreting gender in Bugis society. American Ethnologist, 10(3), 477-493.

Mills, S. (2003). Gender and politeness (Vol. 17). Cambridge University Press.

Monsefi, M., \& Hadidi, Y. (2015). Male and Female EFL Teachers' Politeness Strategies in Oral Discourse and their Effects on the Learning Process and TeacherStudent Interaction. International Journal on Studies in English Language and Literature, 3(1), 1-13.

Samad, I. A., Fitriani, S. S., Patak, A. A., \& Weda, S. (2018). Students' perspectives on genre approach in the "Neglected Communicative Event:" Script defense examination in the English Department. The Asian EFL Journal's International Conference on Research and Publication.

Speer, S. A. (2002). Sexist talk: Gender categories, participants' orientations, and irony. Journal of Sociolinguistics, 6(3), 347-377.

Sülü, A. (2015). Teacher's politeness in EFL class. International Online Journal of Education and Teaching/ISSN: 2148-225X, 2(4), 216-221.

Yule, G. (2016). The study of language. Cambridge university press. 